\title{
Synthesis and characterization of an unusual snowflake-shaped ZSM-5 zeolite with high catalytic performance in the methanol to olefin reaction
}

\author{
Jing Li ${ }^{\text {a,b }}$, Suyao Liu a,b, Huaike Zhang a,c, Enjing Lü c, Pengju Ren a,c, Jie Ren ${ }^{\text {a,c,* }}$ \\ a State Engineering Laboratory for Indirect Coal Liquefaction, Institute of Coal Chemistry, Chinese Academy of Sciences, Taiyuan 030001, Shanxi, China \\ b University of Chinese Academy of Sciences, Beijing 100049, China \\ c National Energy Research Center for Clean Fuels, Synfuels China Co., Ltd., Beijing 101407, China
}

\section{A R T I C L E I N F O}

Article history:

Received 23 July 2015

Accepted 23 September 2015

Published 5 February 2016

Keywords:

ZSM-5 zeolite

Modification

Methanol to olefins

\begin{abstract}
A B S T R A C T
The ZSM-5 zeolite with an unusual snowflake-shaped morphology was hydrothermally synthesized for the first time, and compared with common ellipsoidal and boat-like shaped samples. These samples were characterized by $\mathrm{N}_{2}$ adsorption-desorption, X-ray fluorescence spectroscopy, scanning electron microscopy, $\mathrm{X}$-ray diffraction, magic angle spinning nuclear magnetic resonance, temperature-programmed desorption of ammonia, and infrared spectroscopy of pyridine adsorption. The results suggest that the $\mathrm{BET}$ surface area and $\mathrm{SiO}_{2} / \mathrm{Al}_{2} \mathrm{O}_{3}$ ratio of these samples are similar, while the snowflake-shaped ZSM-5 zeolite possesses more of the (101) face, and distortion, dislocation, and asymmetry in the framework, resulting in a larger number of acid sites than the conventional samples. Catalysts for the methanol to olefin (MTO) reaction were prepared by loading Ca on the samples. The snowflake-shaped Ca/ZSM-5 zeolite exhibited excellent selectivity for total light olefin $(72 \%)$ and propene (39\%) in MTO. The catalytic performance influenced by the morphology can be mainly attributed to the snowflake-shaped ZSM-5 zeolite possessing distortion, dislocation, and asymmetry in the framework, and lower diffusion limitation than the conventional samples.
\end{abstract}

(C) 2016, Dalian Institute of Chemical Physics, Chinese Academy of Sciences. Published by Elsevier B.V. All rights reserved.

\section{Introduction}

ZSM-5 zeolites with medium-sized pores $(0.54 \mathrm{~nm} \times 0.56$ $\mathrm{nm}$ ) and three-dimensional channels were first synthesized by Mobil in 1972. As a type of high-silica zeolite, ZSM-5 is generally prepared from reaction mixtures containing a certain amount of an organic template, which is used as a structure-directing and charge-balancing agent. However, the zeolite morphology can be influenced by many parameters, such as the silica source [1-3], alumina source, template [4-6], and crystallization conditions [7]. Among these parameters, the template is the key factor to control the morphology because different sizes and spatial configurations of the templates can lead to different interactions between the organic templates and zeolite frameworks. Liu et al. [8] reported that spheroidal ZSM-5 zeolites could be synthesized using $n$-butylamine as the template, while after the addition of triethanolamine cuboidal crystals are obtained. Sang et al. [9] concluded that ZSM-5 zeolites with cuboidal, lath-shaped, and boat-like morphologies could be prepared using ethylamine, ethylenediamine, and ethanolamine organic templates, respectively. MFI nanosheets were synthesized with the assistance of diquaternary ammonium-type surfactants $\left(\mathrm{C}_{22} \mathrm{H}_{45}-\mathrm{N}^{+}\left(\mathrm{CH}_{3}\right)_{2}-\mathrm{C}_{6} \mathrm{H}_{12}-\mathrm{N}^{+}\left(\mathrm{CH}_{3}\right)_{2}-\right.$ $\left.\mathrm{C}_{6} \mathrm{H}_{13}\right)$ by Choi et al [10].

\footnotetext{
* Corresponding author. Tel: +86-10-69667855; Fax: +86-10-69667803; E-mail: renjie@sxicc.ac.cn 
ZSM-5 zeolites with different morphologies (e.g., lathshaped, spheroidal, hexagonal, and ellipsoidal morphologies) and channel lengths always have different residence times of the reaction intermediates, which affect the catalytic performance and the product distribution [11,12]. Wang et al. [13] reported that the morphology of ZSM-5 zeolite had a great influence on the product distribution and lifetime of the catalyst in methanol to gasoline reaction. Small-sized ZSM-5 exhibited higher selectivity for $\mathrm{C}_{5+}$ and aromatic hydrocarbon formation and longer lifetime than large-sized ZSM-5. Zhang et al. [14] investigated the influence of the ZSM-5 zeolite crystal size on the methanol to olefin (MTO) reaction, and found that the stability of the small-crystal catalyst was better than that of the large-crystal catalyst. Bhat et al. [15] reported that the morphology of zeolites influenced the selectivity of the toluene disproportionation reaction. Small spheroidal crystal particles were favorable for the formation of $m$-xylene, while $p$-xylene was mainly formed over large cylindrical crystals.

In the present study, ZSM-5 zeolite with an unusual snowflake-shaped morphology was successfully synthesized for the first time, and compared with ellipsoidal and boat-like-shaped samples. Various characterizations were carried out to investigate the structural framework, pores, and acidity. The MTO reaction was chosen as a probe reaction to investigate the effect of the morphology and crystal structure on the catalytic performance.

\section{Experimental}

\subsection{Synthesis of ZSM-5 zeolites}

ZSM-5 zeolite with an unusual snowflake-shaped morphology was synthesized following a previous procedure [16]. Specific amounts of colloidal silica, $\mathrm{Al}_{2}\left(\mathrm{SO}_{4}\right)_{3} \cdot 18 \mathrm{H}_{2} \mathrm{O}, 1,6$-diaminehexane (structure-directing agent (SDA)), $\mathrm{KOH}$, and deionized water were mixed in order. After stirring at room temperature for at least $1 \mathrm{~h}$, the resulting homogeneous gel with molar composition $1.0 \mathrm{SiO}_{2}: 0.26 \mathrm{~K}_{2} \mathrm{O}: 0.02 \mathrm{Al}_{2} \mathrm{O}_{3}: 0.3 \mathrm{SDA}: 40 \mathrm{H}_{2} \mathrm{O}$ was transferred into a stainless-steel autoclave with a capacity of 2 $\mathrm{L}$ and subjected to hydrothermal treatment at $180^{\circ} \mathrm{C}$ for $48 \mathrm{~h}$ in a furnace with autogenous pressure under stirring. The obtained zeolite is hereafter denoted as A.

The gel for the conventional ZSM-5 zeolite synthesis was prepared by slowly adding a mixture of $\mathrm{Al}_{2}\left(\mathrm{SO}_{4}\right)_{3}, \mathrm{H}_{2} \mathrm{SO}_{4}$, and the template agent (ethylamine or ethylenediamine, SDA) to an aqueous solution of $\mathrm{Na}_{2} \mathrm{SiO}_{4}$ (30 wt\% silica) under stirring. The molar composition of the gel was $1.0 \mathrm{SiO}_{2}: 0.02 \mathrm{Al}_{2} \mathrm{O}_{3}: 0.74 \mathrm{SDA}$ : $40 \mathrm{H}_{2} \mathrm{O}$. Finally, the gel was stirred for at least $1 \mathrm{~h}$ at room temperature to obtain a homogenous gel, and then transferred to a 2-L stainless-steel autoclave, which was maintained at $180{ }^{\circ} \mathrm{C}$ for $48 \mathrm{~h}$. The obtained samples are hereafter denoted as B (ethylamine templating agent) and $\mathrm{C}$ (ethylenediamine templating agent).

After crystallization, the products were washed with deionized water to neutral and dried overnight at $120{ }^{\circ} \mathrm{C}$ for $12 \mathrm{~h}$. The organic template was removed by calcination at $550{ }^{\circ} \mathrm{C}$ for $10 \mathrm{~h}$. The zeolites were then converted to the protonic form by ion exchange with $\mathrm{NH}_{4} \mathrm{NO}_{3}$ solution $(0.5 \mathrm{~mol} / \mathrm{L})$ at $80^{\circ} \mathrm{C}$ for $8 \mathrm{~h}$, followed by calcination at $550{ }^{\circ} \mathrm{C}$ in air for $8 \mathrm{~h}$. This process was performed twice. The obtained products are denoted as HA, $\mathrm{HB}$, and $\mathrm{HC}$, for samples A, B, and C, respectively.

\subsection{Catalyst preparation}

Dilute nitric acid was added to a mixture of the molecular sieve and $\mathrm{Al}_{2} \mathrm{O}_{3}$ (mass ratio 4:1), which was extruded to the carriers. The catalysts with 2.0 wt $\%$ Ca-loaded zeolite carriers were prepared by the impregnation method with $\mathrm{Ca}\left(\mathrm{NO}_{3}\right)_{2}$ solutions for the metal precursor. The catalysts were dried at $120{ }^{\circ} \mathrm{C}$ and then calcined at $550{ }^{\circ} \mathrm{C}$ for $4 \mathrm{~h}$. The obtained catalysts are hereafter denoted as Ca-HA, Ca-HB, and Ca-HC.

\subsection{Characterization of the catalysts}

The morphology and crystal size of ZSM-5 were examined with a Quanta 400F scanning electron microscope (FEI, Eindhoven, Netherlands). X-ray diffraction (XRD) patterns were obtained using a Bruker D8 Advance diffractometer (Germany) with $\mathrm{Cu} K_{\alpha}(\lambda=1.5418 \AA, 40 \mathrm{kV}, 40 \mathrm{~mA})$ over a $2 \theta$ range of $5^{\circ}-50^{\circ}$. X-ray fluorescence (XRF) spectroscopy experiments were performed to analyze the $\mathrm{SiO}_{2} / \mathrm{Al}_{2} \mathrm{O}_{3}$ ratio with a Rigaku ZSX Primus II (Japan). The Brunauer-Emmett-Teller (BET) surface area $\left(A_{\mathrm{BET}}\right)$ and pore volume of the ZSM-5 samples were determined by $\mathrm{N}_{2}$ adsorption-desorption measurements using the BET method and $t$-plot method on a Micromeritics ASAP 2020 (USA). Prior to the measurements, all of the samples were degassed at $350{ }^{\circ} \mathrm{C}$ for $8 \mathrm{~h} .{ }^{29} \mathrm{Si}$ and ${ }^{27} \mathrm{Al}$ magic angle spinning (MAS) nuclear magnetic resonance (NMR) spectra were recorded on a Bruker Avance III 600 spectrometer (Germany) with frequencies of 119.2 and $156.4 \mathrm{MHz}$, respectively. The ${ }^{29} \mathrm{Si}$ MAS NMR spectra were acquired using a 7-mm probe with a rotor spin rate of $5 \mathrm{kHz}$. The spectral data were fitted by Dmfit software (http://nmr.cemhti.cnrs-orleans.fr/dmfit). The ${ }^{27} \mathrm{Al}$ MAS NMR spectra were acquired using a 4-mm probe with a rotor spin rate of $13 \mathrm{kHz}$. The acidity was determined by temperature-programmed desorption of ammonia ( $\mathrm{NH}_{3}-\mathrm{TPD}$ ) and Fourier transform infrared (FT-IR) spectroscopy of pyridine adsorption (Py-IR). The $\mathrm{NH}_{3}$-TPD experiments were carried out on a Micromeritics ASAP 2920 (USA) with mass spectra detection. The catalysts (about $200 \mathrm{mg}$ ) were pretreated at $550{ }^{\circ} \mathrm{C}$ under He flow (50 mL/min) for $1 \mathrm{~h}$, cooled to $100{ }^{\circ} \mathrm{C}$ to adsorb $\mathrm{NH}_{3}$, and then purged with He for $1 \mathrm{~h}$. Finally, the adsorbed samples were heated to $600{ }^{\circ} \mathrm{C}$ at $10^{\circ} \mathrm{C} / \mathrm{min}$ under He flow $(50$ $\mathrm{mL} / \mathrm{min}$ ). The Py-IR spectra were recorded with a Bruker Vertex 70 FT-IR spectrometer (Germany). The catalyst samples were ground into a fine powder and pressed into self-supported discs. The sample discs were heated to $400{ }^{\circ} \mathrm{C}$ at $10{ }^{\circ} \mathrm{C} / \mathrm{min}$ under vacuum. Then, He flow with pyridine was introduced into the IR cell at room temperature until adsorption saturation. Spectra were recorded at 200 and $350^{\circ} \mathrm{C}$.

\subsection{Catalytic test}

The MTO catalytic performance of the different catalysts 
was tested in a continuous flow fixed-bed reactor at atmospheric pressure. For each test, the zeolite catalyst ( $5 \mathrm{~mL}$ ) was loaded in the constant temperature zone of the reactor. The reaction conditions were as follows: methanol with liquid hourly space velocity $(\mathrm{LHSV})=2.0 \mathrm{~h}^{-1}, n\left(\mathrm{~N}_{2}\right) / n\left(\mathrm{CH}_{3} \mathrm{OH}\right)=2: 1$, and $T=430-470{ }^{\circ} \mathrm{C}$. For the reaction test of each catalyst sample, five temperature points were sampled with an interval of 3 $h$ between each sampling period, during which the temperature was kept at a constant value. During the sampling period ( $3 \mathrm{~h}$ ), the reactor outlet stream was cooled to $2{ }^{\circ} \mathrm{C}$ and then the gas and liquid products were separated. The gas products were analyzed by two on-line gas chromatographs (Agilent 6890, USA). One was equipped with an HP-MoleSieve5A (102 $\mathrm{m} \times$ $0.50 \mathrm{~mm}$ ) column and a thermal conductivity detector (TCD) for hydrogen and methane, while the other was equipped with an $\mathrm{HP}$-plot $\mathrm{Al}_{2} \mathrm{O}_{3}(50 \mathrm{~m} \times 0.53 \mathrm{~mm})$ column and a flame ionization detector (FID) for alkanes and light olefins. The results were calibrated by the methane concentration. The aqueous and organic phases in the liquid products of the reactor were separated by a decanter. A small portion of the aqueous phase was sent to a gas chromatograph (Agilent 7890A) equipped with an FID and an AB-inowax column for separating water, methanol, and oxygenates. The organic phase was also analyzed by a gas chromatograph (Agilent $7890 \mathrm{~A}$ ) equipped with an FID and an HP-PONA column $(50 \mathrm{~m} \times 0.20 \mathrm{~mm})$ for separating hydrocarbons. After the sampling period, the temperature was increased to a higher value for the next test until the maximum conversion was reached, which led to the reaction tests lasting for about $20 \mathrm{~h}$ for each catalyst sample.

The reaction performance was assessed by methanol conversion and olefin product selectivity according to the following formulas:

$$
\begin{gathered}
X_{\mathrm{MeOH}}=\left(n_{\mathrm{MeOH}, \text { in }}-n_{\mathrm{MeOH}, \mathrm{out}}\right) / n_{\mathrm{MeOH}, \text { in }} \times 100 \% \\
S_{\mathrm{C}_{i}^{=}}=i n_{\mathrm{C}_{i}^{=}} /\left(n_{\mathrm{MeOH}, \text { in }}-n_{\mathrm{MeOH}, \text { out }}\right) \times 100 \%
\end{gathered}
$$

where $i$ represents the number of the carbon atoms in the $\mathrm{C}_{i}^{=}$ olefin, and $n_{\mathrm{MeOH}, \text { in }}$ and $n_{\mathrm{MeOH}, \text { out }}$ represent the number of moles of methanol in the inlet and outlet streams, respectively.

\section{Results and discussion}

ZSM-5 zeolites with different morphologies were synthesized using various templates. The molar compositions of the gels and the $\mathrm{SiO}_{2} / \mathrm{Al}_{2} \mathrm{O}_{3}$ ratios of the products are shown in Table 1. The $\mathrm{SiO}_{2} / \mathrm{Al}_{2} \mathrm{O}_{3}$ ratios of the three samples (34-39) are similar.
Table 1

Molar compositions of the gels and the $\mathrm{SiO}_{2} / \mathrm{Al}_{2} \mathrm{O}_{3}$ ratios of the different ZSM-5 zeolites a.

\begin{tabular}{lcc}
\hline Sample & $n\left(\mathrm{SiO}_{2}\right): n\left(\mathrm{Al}_{2} \mathrm{O}_{3}\right): n(\mathrm{SDA}): n\left(\mathrm{H}_{2} \mathrm{O}\right): n\left(\mathrm{M}_{2} \mathrm{O}\right)^{\mathrm{b}}$ & $n\left(\mathrm{SiO}_{2}\right) / n\left(\mathrm{Al}_{2} \mathrm{O}_{3}\right)$ \\
\hline $\mathrm{HA}$ & $1.0: 0.02: 0.3: 40: 0.26$ & 34 \\
$\mathrm{HB}$ & $1.0: 0.02: 0.74: 40: 0.3$ & 37 \\
$\mathrm{HC}$ & $1.0: 0.02: 0.74: 40: 0.3$ & 39 \\
\hline
\end{tabular}

${ }^{a}$ Crystallization at $180^{\circ} \mathrm{C}$ for $48 \mathrm{~h}$.

${ }^{\mathrm{b}} n\left(\mathrm{M}_{2} \mathrm{O}\right)$ represents $n\left(\mathrm{~K}_{2} \mathrm{O}\right)$ for the HA sample and $n\left(\mathrm{Na}_{2} \mathrm{O}\right)$ for the $\mathrm{HB}$ and $\mathrm{HC}$ samples.

\subsection{SEM}

SEM images of the HA, HB, and HC samples are shown in Fig. 1. The morphologies and particle sizes of the three samples are clearly different. The HA sample has an unusual snowflake-shaped morphology with a crystal size of about $7 \mu \mathrm{m}$. The HB and HC samples have conventional ellipsoidal and boat-like morphologies with crystal sizes of 5 and $6 \mu \mathrm{m}$, respectively.

\subsection{BET surface area}

The micropore size distributions are shown in Fig. 2. The micropore sizes of the different samples have a maximum at about $5.0 \AA$, which is typical for 10 -membered ring pores, demonstrating the presence of the open microporous structure

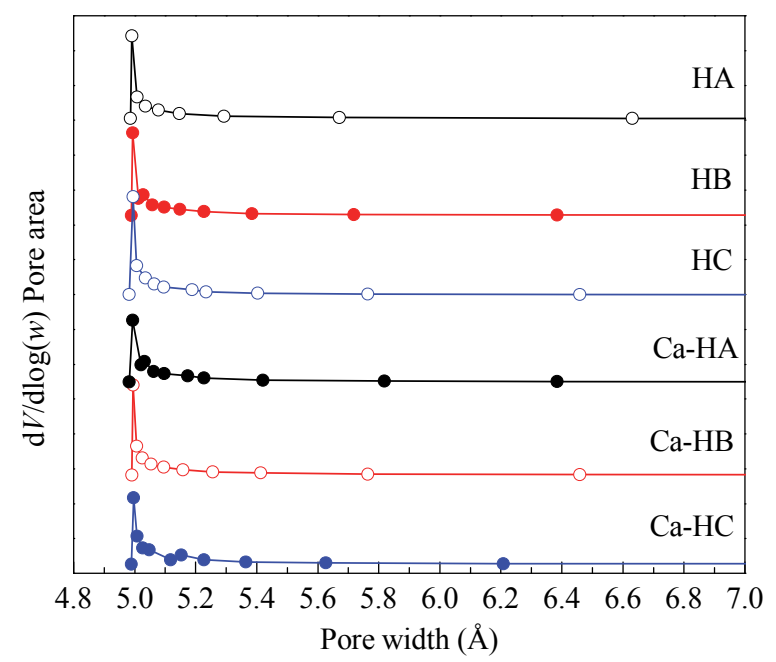

Fig. 2. Micropore size distributions of the different ZSM-5 zeolites and Ca-loaded ZSM-5 zeolites.

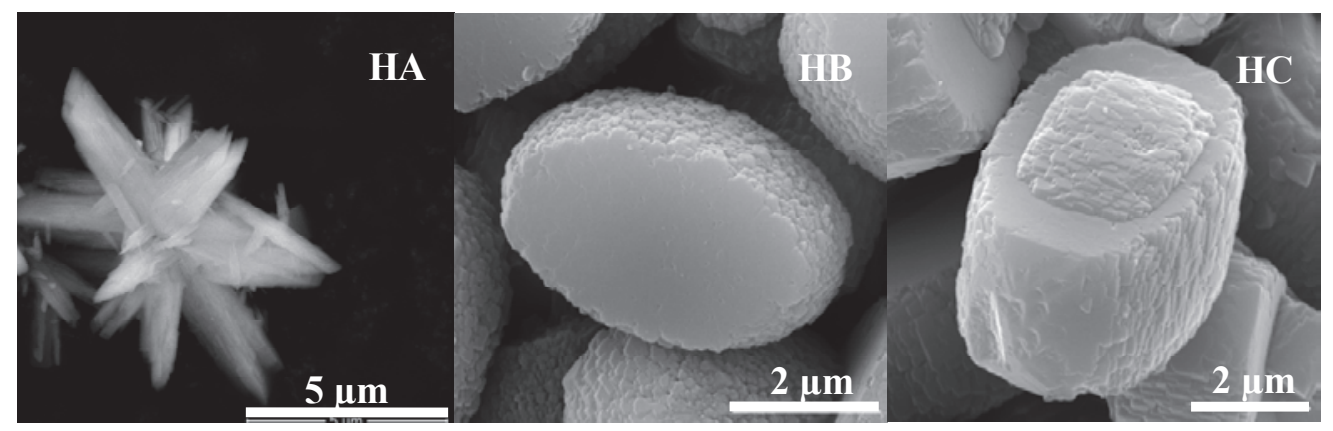

Fig. 1. SEM images of the ZSM-5 samples with different morphologies. 
Table 2

BET specific surface areas and micropore volumes of the different ZSM-5 zeolites and Ca-loaded ZSM-5 zeolites.

\begin{tabular}{lcccc}
\hline Sample & $\begin{array}{c}\text { BET surface } \\
\text { area }\left(\mathrm{m}^{2} / \mathrm{g}\right)\end{array}$ & $\begin{array}{c}\text { Micropore } \\
\text { area }\left(\mathrm{m}^{2} / \mathrm{g}\right)\end{array}$ & $\begin{array}{c}\text { External surface } \\
\text { area }\left(\mathrm{m}^{2} / \mathrm{g}\right)\end{array}$ & $\begin{array}{c}\text { Micropore } \\
\text { volume }\left(\mathrm{cm}^{3} / \mathrm{g}\right)\end{array}$ \\
\hline HA & 365.91 & 246.21 & 119.71 & 0.11 \\
HB & 389.40 & 240.05 & 129.35 & 0.11 \\
HC & 372.19 & 209.32 & 162.87 & 0.10 \\
Ca-HA & 297.40 & 211.42 & 85.98 & 0.10 \\
Ca-HB & 303.35 & 210.35 & 93.00 & 0.10 \\
Ca-HC & 286.70 & 195.30 & 91.40 & 0.09 \\
\hline
\end{tabular}

in the samples. Clear differences between the micropore sizes of the samples cannot be observed because of the limitation of this characterization. The BET surface areas and micropore volumes of the different ZSM-5 zeolites are listed in Table 2. The BET surface areas, micropore areas, and micropore volumes of the three HZSM-5 zeolites are similar. However, the BET surface area and micropore area clearly decrease after $\mathrm{Ca}$ modification, suggesting that Ca diffuses into the channels and blocks the micropores of the zeolites. Furthermore, because of the different crystal structures and orientations of the crystal faces, the micropore areas of the Ca-HA and Ca-HB catalysts exhibit much larger decreases than the Ca-HC catalyst after $\mathrm{Ca}$ loading.

\section{3. $X R D$}

Fig. 3 shows XRD patterns of the HA, HB, and HC samples. All of the samples exhibit a typical characteristic pattern of the MFI-type structure $\left(2 \theta=7.91^{\circ}, 8.76^{\circ}, 23.11^{\circ}\right.$, and $\left.23.84^{\circ}\right)$ [17], while some differences in the intensity of the strongest and second strongest peaks of the different samples can be observed. The ratios of peak intensities at $7.91^{\circ}$ and $8.76^{\circ}$ for the $\mathrm{HA}$ and $\mathrm{HC}$ zeolites are significantly higher than that of the HB zeolite. The diffraction peak at $7.91^{\circ}$ represents the (101) face of the MFI-type structure, while the diffraction peak at $8.76^{\circ}$ can be assigned to the (020) face of the MFI-type structure and corresponds to the straight channel of ZSM-5 zeolites $[18,19]$. The different intensities of the diffraction peaks suggest that

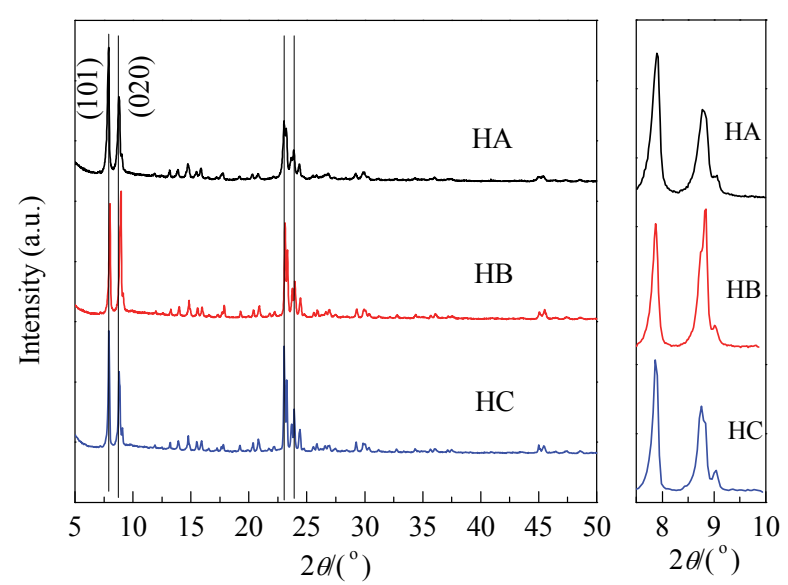

Fig. 3. XRD patterns of the HA, HB, and HC zeolites.
Table 3

Lattice parameters and relative crystallinity (RC) of the HA, HB, and HC zeolites.

\begin{tabular}{lcccccrc}
\hline $\begin{array}{l}\text { Sam- } \\
\text { ple }\end{array}$ & $a(\AA)$ & $b(\AA)$ & $c(\AA)$ & $V\left(\AA^{3}\right)$ & $\begin{array}{c}\mathrm{RC} \\
(\%)\end{array}$ & $\begin{array}{r}\mathrm{Al}_{F_{W}}{ }^{\mathrm{a}} \\
(\%)\end{array}$ & $\begin{array}{c}\mathrm{Al}_{\mathrm{EFW}}{ }^{\mathrm{b}} \\
(\%)\end{array}$ \\
\hline HA & 20.1419 & 20.1413 & 13.4532 & 5457.7487 & 94.5 & 85 & 15 \\
HB & 20.1037 & 19.9589 & 13.4178 & 5383.8619 & 98.8 & 91 & 9 \\
HC & 20.0920 & 20.1367 & 13.4410 & 5438.0482 & 100.0 & 92 & 8 \\
\hline
\end{tabular}

a The relative concentration of tetra-coordinated framework aluminum, which is determined by integrating the NMR signal between the chemical shifts at 30 and 80 ppm.

b The relative concentration of hexa-coordinated extra-framework aluminum, which is determined by integrating the NMR signal between -20 and 20 ppm.

the crystal orientations of the ZSM-5 zeolites are different, further indicating the different directions of the straight channels. For the HB sample, the strongest diffraction peak at $8.76^{\circ}$ reveals that more of the (020) face is exposed than the (101) face. However, because of twin crystal intergrowth, part of the (020) face of the HC sample is covered, so the intensity of the $8.76^{\circ}$ peak is weaker than that of the other samples, as shown in Fig. 3. The XRD pattern of the HA zeolite is similar to that of the HC zeolite, while the relative crystallinity of the former is lower than that of the latter (Table 3), suggesting that the (101) face of the HA sample is mainly exposed.

According to the XRD patterns, the HB zeolite has more of the (020) face, while the (020) face of the HC sample is covered because of twin crystal interlaced growth, as shown in Fig. 4 [20]. Because of the relatively complex crystal orientation of the snowflake-shaped HA sample, it still needs to be further studied and characterized.

Using the least squares method, the zeolite unit cell parameters and unit cell volume calculated from the XRD peaks in the range of $7^{\circ}-30^{\circ}$ are listed in Table 3 . The unit cell parameters and volume decrease in the order HA $>$ HC > HB. This suggests that the micropore skeleton structure of the snowflake-shaped HA zeolite is different from the other two samples.

\subsection{MAS NMR}

MAS NMR is a powerful tool to analyze atom coordination in zeolite frameworks. The ${ }^{27} \mathrm{Al}$ MAS NMR spectra of all of the samples show two signals (Fig. 5). In general, chemical shifts at 54 and $0 \mathrm{ppm}$ are assigned to tetra-coordinated framework aluminum and hexa-coordinated extra-framework aluminum [21], respectively, indicating that most of the $\mathrm{Al}$ atoms are in the framework of the zeolite structure. The peak intensities of the HA sample are lower than that of HB and HC samples be-
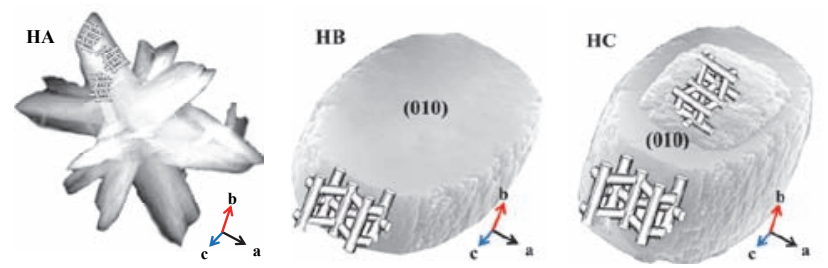

Fig. 4. Schematic pore structures of the HA, HB, and HC zeolites. 


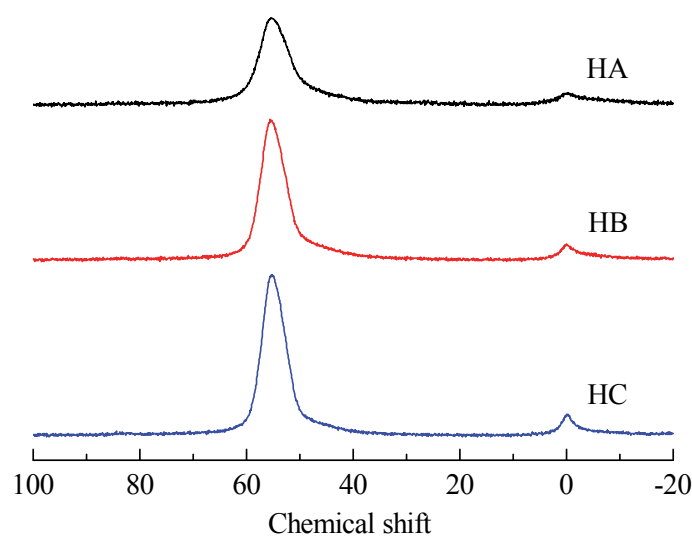

Fig. 5. ${ }^{27} \mathrm{Al}$ MAS NMR spectra of the HA, HB, and HC zeolites.

cause of chemical vibration of the coordination environment of $\mathrm{Al}$ atoms (e.g., weak dipole interactions). This observation indicates the presence of distortion, dislocation, and asymmetry in the cross-crystal boundary of the HA zeolite [22]. The relative distributions of these two $\mathrm{Al}$ species obtained by deconvolution of the ${ }^{27} \mathrm{Al}$ MAS NMR spectra are given in Table 3. Compared with the HA sample, the relative concentration of tetra-coordinated $\mathrm{Al}$ signals in the spectra of the $\mathrm{HB}$ and $\mathrm{HC}$ samples are more intense (Fig. 5), which is consistent with the results of the relative crystallinity of the three samples in Table 3.

Fig. 6 shows the ${ }^{29} \mathrm{Si}$ MAS NMR spectra of the HA, HB, and $\mathrm{HC}$ samples. In these cases, the resonance at around -118.0 ppm is assigned to $\mathrm{Si}(4 \mathrm{Si})$ sites, while the resonance at -115.1

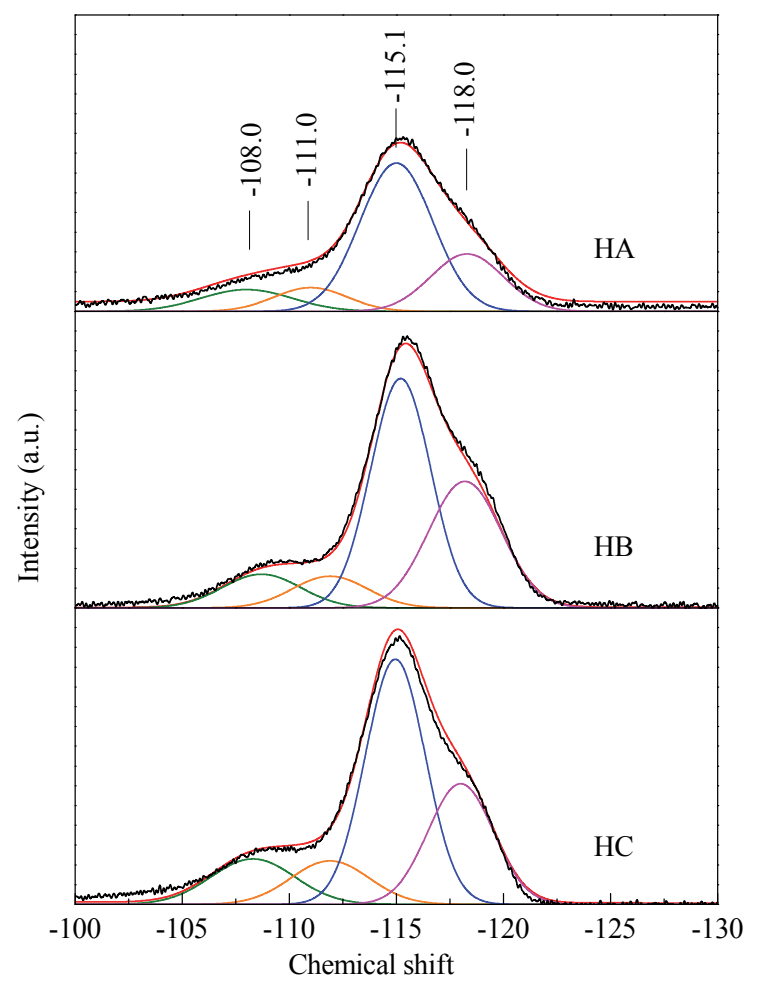

Fig. 6. ${ }^{29} \mathrm{Si}$ MAS NMR spectra of HA, HB, and HC zeolites. The black curve represents the peak of the original data; the red curve represents the peak sum of all the fitted curves. ppm originates from $\mathrm{Si}(4 \mathrm{Si})$ sites with $1 \mathrm{H}(\mathrm{OH}$ group) as the next-nearest neighbor [23]. The bands around -111.0 and -108.0 ppm correspond to the Si(3Si) sites [24]. After deconvolution, the signal of HA at $-115.1 \mathrm{ppm}$ is significantly wider than the signals of the conventional samples, further confirming the presence of distortion, dislocation, and asymmetry in the cross-crystal boundary of the HA zeolites [25,26]. Consequently, the ${ }^{27} \mathrm{Al}$ and ${ }^{29} \mathrm{Si}$ MAS NMR spectra are consistent with the XRD results.

\section{5. $\mathrm{NH}_{3}-\mathrm{TPD}$}

$\mathrm{NH}_{3}$-TPD profiles of the HZSM-5 zeolites and Ca/HZSM-5 catalysts are shown in Fig. 7. The resulting peaks are classified as two types of acid sites with different acid strengths, corresponding to the peak maximum at the desorption temperature. The temperature ranges are $400-450{ }^{\circ} \mathrm{C}$ for strong acid sites, and $200-230{ }^{\circ} \mathrm{C}$ for weak acid sites. The total number of acid sites decreases in the order $\mathrm{HA}>\mathrm{HC}>\mathrm{HB}$. The larger number of acid sites for HA is probably because of the presence of distortion, dislocation, and asymmetry in the framework of the HA zeolite, as confirmed by XRD and MAS NMR. After modification with $\mathrm{Ca}$, the total acidity of all of the catalysts, especially the strong acidity, significantly decreases, and some differences can be observed. The total number of acid sites of HA markedly decreases with Ca loading. However, the total acidity of HC only slightly decreases with Ca loading. This result may be because the introduced metal not only interacts with acid sites on the surface but also with acid sites located in the micropores. For the snowflake-shaped Ca-HA and ellipsoidal Ca-HB catalysts, the $\mathrm{Ca}^{2+}$ ions favorably diffuse into the micropores and interact with acid sites. However, diffusion of $\mathrm{Ca}^{2+}$ ions is limited by the zigzag channels of the HC zeolite, leading to Ca mainly interacting with acid sites at the surface. The variation of the surface areas of the different samples before and after Ca loading can give indirect evidence of the Ca spatial distribution. The micropore areas and external surface areas of the three samples after loading Ca exhibit different trends. The micropore areas of HA and HB exhibit a much sharper decrease than that of HC

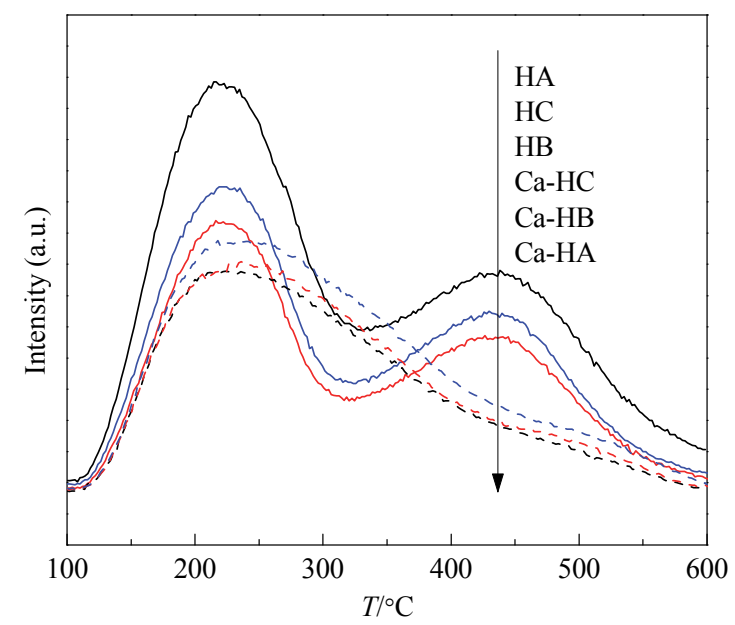

Fig. 7. $\mathrm{NH}_{3}$-TPD profiles of the $\mathrm{HA}, \mathrm{HB}$, and $\mathrm{HC}$ zeolites, and $\mathrm{Ca}-\mathrm{HA}$, Ca-HB, and Ca-HC zeolite catalysts. 
Table 4

Acid amounts of the different ZSM-5 zeolites and Ca-loaded ZSM-5 zeolites.

\begin{tabular}{lccccc}
\hline & \multicolumn{3}{c}{ Acidity $(\mu \mathrm{mol}$ Py/g sample) } \\
\cline { 2 - 3 } \cline { 2 - 3 } \cline { 5 - 6 } \cline { 5 - 6 } & \multicolumn{2}{c}{ Weak acid sites } & & \multicolumn{2}{c}{ Strong acid sites } \\
\cline { 2 - 3 } & \multicolumn{1}{c}{ B } & L & & B & L \\
\hline HA & 208 & 103 & & 163 & 44 \\
HB & 267 & 116 & & 266 & 90 \\
HC & 284 & 121 & & 260 & 72 \\
Ca-HA & 23 & 159 & & 13 & 60 \\
Ca-HB & 33 & 242 & & 16 & 156 \\
Ca-HC & 37 & 218 & & 16 & 60 \\
\hline
\end{tabular}

after loading with Ca. However, the external surface areas of HA and HB exhibit a smaller decrease than that of HC because of the larger number of zigzag channels with high diffusion limitation in the HC zeolite than in the HA and HB samples.

\section{6. $P y-I R$}

The acid types of the different zeolites were investigated by Py-IR. The density and distribution of the acid sites were estimated according to the areas of the corresponding IR bands. The results are summarized in Table 4. The amount of $\mathrm{B}$ acid sites is in the order $\mathrm{HC} \approx \mathrm{HB}>\mathrm{HA}$, which is not consistent with the $\mathrm{NH}_{3}$-TPD results. This may be because of the effects of the geometric structure of the snowflake-shaped HA zeolite and the distortion and dislocation of the grain boundaries on the pore structure in the framework. This could suppress diffusion of pyridine molecules, which are larger than $\mathrm{NH}_{3}$ molecules, and thus lead to decreased adsorption of pyridine molecules on the acid sites. After modification with $\mathrm{Ca}$, the total amount of acid sites markedly decreases. The amount of B acid sites decreases, while the amount of $\mathrm{L}$ acid sites exhibits the opposite trend, probably owing to the B acid sites of HZSM-5 interacting with $\mathrm{Ca}^{2+}$ to form $\mathrm{L}$ acid sites $\left(\mathrm{Ca}^{2+}+\mathrm{OH}^{-} \rightarrow \mathrm{Ca}(\mathrm{OH})^{+}\right)[27,28]$

\subsection{Catalytic performance in the MTO reaction}

According to the above characterizations of the different samples, it can be inferred that these catalysts with similar surface areas and $\mathrm{SiO}_{2} / \mathrm{Al}_{2} \mathrm{O}_{3}$ ratios will exhibit different cata- lytic performance because of the presence of distortion, dislocation, and asymmetry in the framework of the HA sample, which has a completely different morphology than the other zeolites. The MTO reaction was chosen as a probe reaction to further investigate the effect of zeolite morphology on catalytic performance.

To rationalize the observed data, a brief review of the mechanistic aspects of the MTO reaction is required. First, methanol is dehydrated to form dimethyl ether (DME) at the L acid sites. Second, methanol and DME react through the hydrocarbon pool mechanism to form the carbenium ions $\left(\mathrm{C}_{x}^{+}\right)$, which can then be converted to $\mathrm{C}_{2}-\mathrm{C}_{4}$ olefins. Finally, $\mathrm{C}_{2}-\mathrm{C}_{4}$ olefins react with each other to form $n$-alkanes and aromatics at $\mathrm{B}$ acid sites [29,30].

The catalytic performance of the $\mathrm{Ca} / \mathrm{HZSM}-5$ catalysts for the MTO reaction is shown in Fig. 8. The selectivity of total olefin and propene formation over the different catalysts first increases and then decreases with increasing reaction temperature. The product distribution over the different catalysts at about $100 \%$ conversion is shown in Table 5.

The snowflake-shaped zeolite catalyst (Ca-HA) exhibits the highest selectivity for olefin (72\%) and propene (39\%) among all of the catalysts. According to the MTO reaction mechanism, the presence of B acid sites always induces cyclization and dehydrogenation of light olefins. Thus, the ellipsoidal Ca-HB catalyst with more B acid sites exhibits lower selectivity for light olefin formation than the Ca-HA catalyst. Moreover, compared with the HB zeolite, the channel length of the snowflake-shaped HA zeolite is much shorter, leading to lower diffusion limitation and shorter residence time, which further suppresses hydrogenation and/or aromatization of propene.

Among the three catalysts, the Ca-HC catalyst exhibits the lowest selectivity for light olefin formation because the HC zeolite has the most zigzag channels, which suppress diffusion and increase the residence time of the products, leading to the further conversion of light olefins at B acid sites.

\section{Conclusions}

The ZSM-5 zeolite with an unusual snowflake-shaped morphology was hydrothermally synthesized and compared with conventional ellipsoidal and boat-like-shaped ZSM-5 zeolite

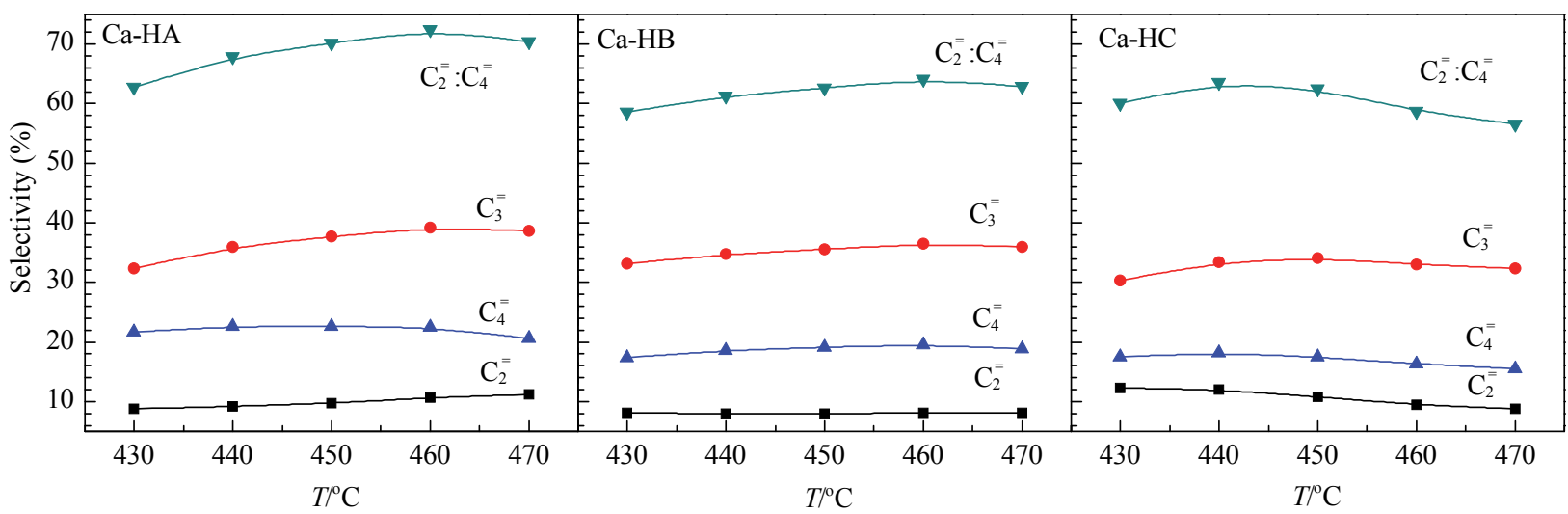

Fig. 8. Variation of the selectivity of $\mathrm{C}_{2}-\mathrm{C}_{4}$ olefin formation over different Ca/ZSM-5 catalysts. $C_{2}^{=}$: ethylene; $C_{3}^{=}$: propene; $C_{4}^{=}$: butylene. 
Table 5

Variation of the selectivity of products over different Ca/ZSM-5 catalysts at about $100 \%$ methanol conversion.

\begin{tabular}{|c|c|c|c|c|c|c|c|c|}
\hline \multirow{2}{*}{ Catalyst } & \multirow{2}{*}{$X_{\mathrm{MeOH}} / \%$} & \multicolumn{7}{|c|}{ Selectivity (\%) } \\
\hline & & $\mathrm{C}_{2}^{=}$ & $\mathrm{C}_{3}^{=}$ & $\mathrm{C}_{4}^{=}$ & Alkanes & Aromatics & Total $=\mathrm{a}$ & $\mathrm{C}_{3}^{=} / \mathrm{C}_{2}^{=}$ \\
\hline Ca-HA & 99.78 & 10.67 & 39.22 & 22.52 & 22.89 & 4.70 & 72.41 & 3.68 \\
\hline Ca-HB & 99.24 & 8.10 & 36.49 & 19.51 & 32.25 & 3.66 & 64.09 & 4.50 \\
\hline Ca-HC & 98.13 & 9.43 & 32.96 & 16.34 & 35.25 & 6.02 & 58.73 & 3.49 \\
\hline
\end{tabular}

a The sum of ethylene, propene, and butylene.

samples. Because of the presence of distortion, dislocation, and asymmetry in the framework, the snowflake-shaped ZSM-5 zeolite possesses a higher amount of acid sites and lower diffusion limitation than the conventional zeolite samples. Catalysts for the MTO reaction were prepared by loading Ca on the three samples. The snowflake-shaped Ca/ZSM-5 zeolite catalyst exhibits excellent selectivity for light olefin formation (72\%) and good selectivity for propene formation (39\%) in the MTO reaction. Our results demonstrate how the macroscopic zeolite morphology affects the microscopic structure and catalytic performance.

\section{Acknowledgments}

The authors are grateful to Synfuels China Co. Ltd. for the financial and equipments support.

\section{References}

[1] R. M. Mohamed, H. M. Aly, M. F. El-Shahat, I. A. Ibrahim, Microporous Mesoporous Mater., 2005, 79, 7.

[2] N. B. Chu, J. H. Yang, C. Y. Li, J. Y. Cui, Q. Y. Zhao, X. Y. Yin, J. M. Lu, J. Q. Wang, Microporous Mesoporous Mater., 2009, 118, 169.

[3] H. Feng, C. Y. Li, H. H. Shan, Appl. Clay Sci., 2009, 42, 439.

[4] J. Lee, U. G. Hong, S. Hwang, M. H. Youn, I. K. Song, Fuel Process Technol., 2013, 108, 25.

[5] R. Karimi, B. Bayati, N. Charchi Aghdam, M. Ejtemaee, A. A. Ba- baluo, Powder Technol., 2012, 229, 229.

[6] O. A. Fouad, R. M. Mohamed, M. S. Hassan, I. A. Ibrahim, Catal. Today, 2006, 116, 82.

[7] R. M. Mohamed, O. A. Fouad, A. A. Ismail, I. A. Ibrahim, Mater. Lett., 2005, 59, 3441.

[8] C. Y. Liu, Y. Q. Liu, M. Cui, H. L. Liu, P. Zhang, R. Xu, Ind. Catal., 2011, 19(6), 37.

[9] S. Y. Sang, F. X. Chang, Z. M. Liu, C. Q. He, Y. L. He, L. Xu, Catal. Today, 2004, 93-95, 729.

[10] M. Choi, K. Na, J. Kim, Y. Sakamoto, O. Terasaki, R. Ryoo, Nature, 2009, 461, 246.

[11] K. Y. Wang, X. S. Wang, Microporous Mesoporous Mater., 2008, 112, 187.

[12] N. Viswanadham, S. K. Saxena, Fuel, 2013, 105, 490.

[13] F. Wang, X. L. Jia, J. X. Hu, J. Ren, Y. W. Li, Y. H. Sun, J. Mol. Catal. (China), 2003, 17, 140.

[14] S. H. Zhang, B. L. Zhang, Z. X. Gao, Y. Z. Han, J. Fuel Chem. Technol,, 2010, 38, 483.

[15] Y. S. Bhat, J. Das, K. V. Rao, A. B. Halgeri, J. Catal., 1996, 159, 368.

[16] J. Ren, H. K. Zhang, E. J. Lü, S. Y. Liu, J. Li, Y. Yang, Y. W. Li, CN Patent 10441006.7. 2015.

[17] G. W. Ma, Z. Q. Xu, H. N. Zhang, J. B. Yang, X. G. Ge, J. R. Peng, J. Chin. Ceram. Soc., 2005, 33, 180.

[18] C. Y. Liu, W. Y. Gu, D. J. Kong, H. C. Guo, Microporous Mesoporous Mater., 2014, 183, 30.

[19] C. Y. Liu, D. J. Kong, H. C. Guo, Microporous Mesoporous Mater., 2014, 193, 61.

[20] Y. Fan, D. Lei, G. Shi, X. J. Bao, Catal. Today, 2006, 114, 388.

[21] G. Wu, W. Wu, X. Wang, W. Zan, W. J. Wang, C. Li, Microporous

\section{Graphical Abstract}

Chin. J. Catal., 2016, 37: 308-315 doi: 10.1016/S1872-2067(15)60979-2

Synthesis and characterization of an unusual snowflake-shaped ZSM-5 zeolite with high catalytic performance in the methanol to olefin reaction

Jing Li, Suyao Liu, Huaike Zhang, Enjing Lü, Pengju Ren, Jie Ren*

Institute of Coal Chemistry, Chinese Academy of Sciences; University of Chinese Academy of Sciences; Synfuels China Co. Ltd.
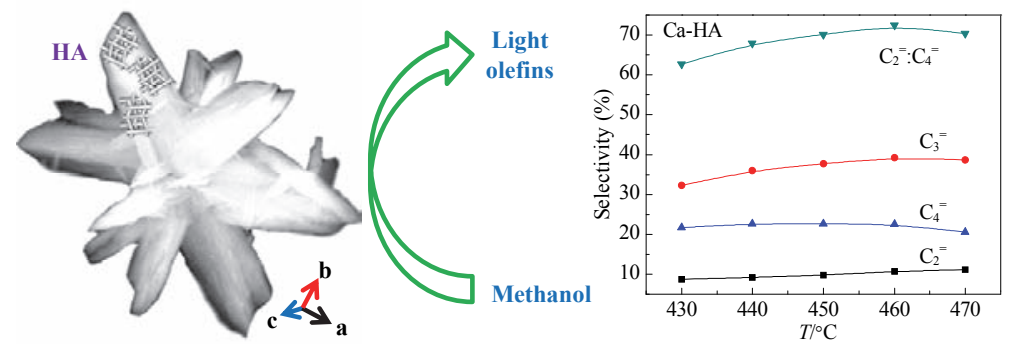

An unusual snowflake-shaped ZSM-5 zeolite (HA) with a large amount of acid sites is extensively investigated. The corresponding Ca-loaded catalyst exhibits excellent selectivity for light olefin formation (72\%) in the methanol to olefin reaction. 
Mesoporous Mater., 2013, 180, 187.

[22] X. C. Zhu, L. L. Wu, P. C. M. M. Magusin, B. Mezari, E. J. M. Hensen, J. Catal., 2015, 327, 10.

[23] C. J. H. Jacobsen, C. Madsen, T. V. W. Janssens, H. J. Jakobsen, J. Skibsted, Microporous Mesoporous Mater., 2000, 39, 393.

[24] J. K. Reddy, K. Motokura, T. Koyama, A. Miyaji, T. Baha, J. Catal., 2012, 289, 53.

[25] Y. P. Khitev, Y. G. Kolyagin, I. I. Ivanova, O. A. Ponomareva, F. Thibault-Starzyk, J. P. Gilson, C. Fernandez, F. Fajula, Microporous
Mesoporous Mater., 2011, 146, 201.

[26] Y. P. Khitev, I. I. Ivanova, Y. G. Kolyagin, O. A. Ponomareva, Appl. Catal. A, 2012, 441-442, 124.

[27] D. S. Mao, Q. S. Guo, T. Meng, Acta Phys.-Chim. Sin., 2010, 26, 2242.

[28] Y. G. Li, W. H. Xie, S. Yong, Appl. Catal. A, 1997, 150, 231.

[29] J. Wang, Y. S. Jin, Y. H. Zhou, J. B. Mo, Appl. Chem. Ind., 2012, 41, 756.

[30] M. Kaarsholm, B. Rafii, F. Joensen, R. Cenni, J. Chaouki, G. S. Patierce, Ind. Eng. Chem. Res., 2010, 49, 29.

\title{
特殊形貌类雪花状ZSM-5分子篮的合成、表征及甲醇制烯烃催化性能
}

\author{
李 静 ${ }^{\mathrm{a}, \mathrm{b}}$, 刘粟侥 ${ }^{\mathrm{a}, \mathrm{b}}$, 张怀科 ${ }^{\mathrm{a}, \mathrm{c}}$, 吕恩静 ${ }^{\mathrm{c}}$, 任鹏举 ${ }^{\mathrm{a}, \mathrm{c}}$, 任 杰 $^{\mathrm{a}, \mathrm{c}, *}$ \\ ${ }^{\mathrm{a}}$ 中国科学院山西煤炭化学研究所煤间接液化国家工程实验室, 山西太原030001 \\ $\mathrm{b}$ 中国科学院大学, 北京 100049 \\ $\mathrm{c}$ 中科合成油技术有限公司, 北京 101407
}

摘要: 美国Mobil公司于1972年首先开发的ZSM-5分子筛是一种高硅三维交叉孔道的沸石分子䇛, 其孔道结构具有良好的择形作 用, 因此被广泛应用于芳构化、异构化、烷基化和催化裂化等工业催化过程. ZSM-5分子篮的催化性能与其晶粒尺寸、酸性及形 貌等密切相关. 改变合成方法和制备参数可以合成出不同形貌的ZSM-5分子篮, 但目前关于ZSM-5分子笁形貌对其物理化学性质 和催化性能的影响报道较少.

本文通过改变模板剂类型, 采用水热合成法, 制备出了类雪花状、椭圆柱状和夹心糖状三种不同形貌的ZSM-5分子䇻. 通过X 射线苂光光谱 $(\mathrm{XRF}) 、 \mathrm{~N}_{2}$ 物理吸脱附 $(\mathrm{BET}) 、$ 扫描电镜 $(\mathrm{SEM}) 、 \mathrm{X}$ 射线衍射 $(\mathrm{XRD})$ 、固体核磁共振 $(M A S \mathrm{NMR}) 、 \mathrm{NH}_{3}$ 程序升温脱附 $\left(\mathrm{NH}_{3}-\mathrm{TPD}\right)$ 及吸附吡啶的红外光谱(Py-IR)等手段对不同形貌分子篎的物理化学性质、形貌、晶体骨架结构和酸性进行了表征. 采 用浸渍法制备了 Ca/HZSM-5催化剂, 以甲醇制烯烃(MTO)为探针反应, 着重研究了ZSM-5 分子篎形貌和晶体结构特性对其酸性和 催化性能的影响.

合成的三种不同形貌的ZSM-5分子篮具有相近的 $\mathrm{SiO}_{2} / \mathrm{Al}_{2} \mathrm{O}_{3}$ 比和比表面积. XRD结果表明, 通过改变模板剂类型, 可制得结

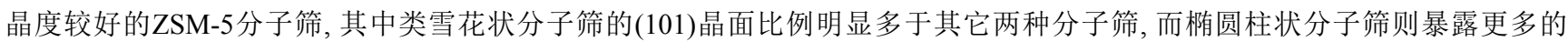
(020)晶面. ${ }^{27} \mathrm{Al}$ MAS NMR结果表明, 绝大部分Al都以四配位形式存在于三种分子篮骨架中, 而类雪花状分子篮的峰强度较低, 这 是由于A1的配位环境不同(偶极作用弱), 说明在类雪花状分子耖的交叉晶面中存在大量扭曲、错位和不对称结构; 与其它两种分 子篮相比, 类雪花状分子篎的 ${ }^{29} \mathrm{Si}$ MAS NMR谱峰宽化, 进一步证明该分子篮骨架结构中存在扭曲、错位和不对称性. $\mathrm{NH}_{3}-\mathrm{TPD}$ 结 果表明, 类雪花状HZSM-5分子笁的酸量明显高于其它两种分子篮, 在 $\mathrm{SiO}_{2} / \mathrm{Al}_{2} \mathrm{O}_{3}$ 比相近的情况下, 类雪花状HZSM-5分子䇥晶体 骨架结构的错位、扭曲和不对称性造成了该分子笁中酸量增加; 但Py-IR结果表明, 类雪花状HZSM-5分子笁的酸量低于其它两种 分子筷, 这与 $\mathrm{NH}_{3}$-TPD结果有差异, 主要是由于类雪花状分子篮几何空间结构和晶界处的扭曲、错位对孔道结构的影响, 不利于比 $\mathrm{NH}_{3}$ 分子大的吡啶分子的扩散, 进而影响了吡啶分子在酸性位上的吸附.

三种不同形貌的ZSM-5分子笁经Ca改性后比表面积和微孔比表面积均明显下降, 其中类雪花状和椭圆柱状催化剂的微孔比 表面积下降幅度较大, 外比表面积下降幅度较小. 这是因为各分子笁的晶体结构和晶面的取向差异, 导致 $\mathrm{Ca}$ 离子在分子筷上的扩 散行为不同. 同时, 经 $\mathrm{Ca}$ 改性后, 三个催化剂的总酸量均有下降, 尤其是类雪花状分子篮酸量下降较为明显, 表明其中 $\mathrm{Ca}$ 离子更容 易扩散到分子笁孔道内, 与更多的酸性位作用, 而夹心糖状分子篮表面具有更多的Z字形孔道, 不利于Ca离子扩散到分子笁孔道 内, 因而酸量下降较少. Py-IR结果表明, Ca改性后催化剂的总酸量下降, 尤其是B酸明显降低, L酸略有增加, 其中类雪花状ZSM-5 分子篮催化剂的B酸量最低.

甲醇制烯烃反应评价结果表明, 随着反应温度升高, 三个催化剂的总烯选择性和丙烯选择性均呈先升高后降低的趋势. 类雪 花状ZSM-5分子笁催化剂在甲醇转化率相近时具有最高的烯烃选择性, 在反应温度为 $460{ }^{\circ} \mathrm{C}$ 时, 总烯烃选择性为 $72 \%$, 丙烯选择性 达39\%.

关键词: ZSM-5分子笠; 钲改性; 甲醇制烯烃

收稿日期: 2015-07-23. 接受日期: 2015-09-23. 出版日期: 2016-02-05.

*通讯联系人. 电话: (010)69667855; 传真: (010)69667803; 电子信箱: renjie@sxicc.ac.cn

本文的英文电子版由Elsevier出版社在ScienceDirect上出版(http://www.sciencedirect.com/science/journal/18722067). 